\title{
Ogya ne atuduro nna faako - Fire and gunpowder do not sleep together: Teaching and learning Materials Science and Engineering with African proverbs
}

\author{
Kwadwo Osseo-Asare \\ Distinguished Professor \\ Department of Materials Science and Engineering \\ Department of Energy and Mineral Engineering \\ Penn State University, USA \\ Email: ako1@psu.edu
}

Submitted: June 28, 2018 / Accepted: February 15. 2019 / Published: October 4, 2019

\begin{abstract}
In 2008, on a sabbatical leave in the Department of Materials Science and Engineering at the University of Ghana, I was assigned a new course, Materials and the Future. Materials science and engineering is concerned with the science and engineering of "stuff." This paper recounts my motivation for using African proverbs as a medium of instruction in this course. I also share highlights of my experiences and those of the students. Engineering schools worldwide are struggling with how to promote cognitive learning and creativity among today's generation of students. The technologically advanced countries have the challenge of weaning students away from overdependence on pre-existing solutions easily accessible via the Internet. In Africa it is tempting for students to assume that all technological advances come from abroad and that they should just wait passively to receive these blessings. This paper argues that the indirection characteristic of proverbial discourse can encourage students to develop a conceptual understanding of materials science and engineering rooted in the African soil.
\end{abstract}

Keywords: proverbial discourse, materials science and engineering, deconstruction, indirection, pedagogy 


\section{Introduction}

If all of engineering is viewed as a building, then the field of materials science and engineering represents the foundation. Materials Science and Engineering (MSE) as an academic discipline focuses on the science and engineering of "stuff." All engineers use stuff. Civil engineers build dams with concrete, a mixture of sand, cement, and water. Mechanical engineers rely on metals, polymers (plastic), and glass to build machines and cars; transportation engineers need gravel, asphalt, and concrete to make roads; electrical and electronic engineers use silicon, other semiconductors, and metals to manufacture solar panels, build computers, and so on. It is no wonder historians of human development have used materials to mark stages of technological advancement, i.e., the stone age, bronze age, iron age, etc. (Thrower, 1991; Callister and Rethwisch, 2014). There may be some disagreement in what to call the period in which we currently live. Many will like to call it the Information Age, given the obvious dominance of computers, cell phones, and the internet. Still one may argue that without materials (metals, ceramics, glass, semiconductors, organic polymers) there would be no computers and cell phones and, therefore, this might be designated the Materials Age.

I spent the second semester of the 2007/2008 academic year as a visiting professor of materials science and engineering in the new School of Engineering Sciences at the University of Ghana. Following conversations with the then Dean, I had assumed that I would most likely be teaching the course Introduction to Ceramics. This is not a course I teach in my home university, but I was willing to consider it since I thought it could provide me with an opportunity to develop some new approaches into the treatment of the relevant topics. A few days before classes started, I found out by accident from a colleague that I had been assigned a different course. Noticing my surprise, the colleague walked me to the bulletin board where it was clearly posted that my assigned course was MSEN 325, Materials and the Future. I have since learned that this is not unusual practice in many other African universities. Instructors are assigned courses sometimes as late as the first week of classes.

According to the official course description, MSEN 325 was to focus on the "Survey of selected materials that have potential impact in the advanced economy of the future": 
Osseo-Asare, K. /Ogya ne atuduro nna faako - Fire and gunpowder do not sleep together

- Materials for clean energy

- Porous materials

- Diamond and hard materials

- New polymers

- $\quad$ Surfaces and interfaces

- $\quad$ Photonic materials

- Materials for information storage

- $\quad$ Smart materials

- $\quad$ Biomedical materials

Clearly, I could not simply use the instructional items, including the visuals, I had prepared for the previous course (Introduction to Ceramics). Now I faced many challenges. How does one teach a course like this in an environment where:

- There are almost no textbooks,

- There are no serious library resources, and

- Internet access is temperamental at best.

Fortunately, I remembered a book I had noticed in the University Bookstore during the first week we arrived on the campus: $B u M e B \varepsilon$; Proverbs of the Akans (Appiah et al., 2007). It occurred to me that African proverbs might provide an opportunity to link technological advances to the local (Ghanaian, African) environment, thereby encouraging engineering students in Africa to go beyond textbook engineering. I was aware of concerns being raised by various observers about the lack of connection between science education and scientific thinking. For example, as noted by Essegbey (2006),

Ghana makes science compulsory throughout secondary education, and an astonishing 46 per cent of students in Ghanaian universities and polytechnics are enrolled in science-related programmes. Yet all this activity has had little impact. There remains a huge gap between teaching and learning science and truly assimilating it so that it guides our thinking, decisions and actions.

\section{What is Materials Science and Engineering?}

At a minimum, the field of materials science and engineering (MSE) may be envisioned as a four-legged-stool, the legs being property, structure, processing, and performance (Thrower, 1991; Callister and Rethwisch, 2014). 


\section{Property}

Property may be understood in terms of stimulus-response phenomena. A property registers the response of a material to a given external stimulus. For example, if specimens of two different materials are squeezed, the subsequent shape changes may be different. The shape changes themselves are a consequence of the mechanical properties and the observed differences in shape change reveal differences in the mechanical properties of the specimens. Beside mechanical, other properties include electrical, magnetic, optical, thermal, and degradational.

\section{Structure}

Structure refers to the inner architecture of a material. This architecture can be perceived at different scales. At the innermost, the subatomic level, the structure is based on positively charged particles (nuclei) and negatively charged particles (electrons). Moving outwards, there is the atomic level which relates to how atoms are arranged with each other into larger aggregates called molecules. At the microscopic level atoms and molecules further combine into larger entities that are observable through appropriate microscopes. Finally, we get to the macroscopic level where the naked eye can recognize the structural features.

\section{Processing}

The third leg of the MSE stool, processing, is best appreciated through a culinary lens. A piece of yam may be boiled, roasted, or fried. These are three different processing methods. If you want the prepared yam to be crunchy when eaten you will not boil it. Thus, we can see that if crunchiness is a desired property, then we need to prepare or process the yam in an appropriate way.

\section{Performance}

Performance, the fourth leg, links properties to the practical application of the material. Accordingly, if the guests to a party prefer crunchy appetizers, then the performance of a fried piece of yam will be rated higher than that of boiled yam - a guest will derive more joy from experiencing the crunch-crunch.

There are three main classes of materials, i.e., metals (e.g., gold, iron), ceramics (e.g., bricks, clay pots, and glass), and polymers (e.g., plastics, leather, and wood). Just as the individual legs do not constitute the MSE stool, one must not confuse an article with the materials from which it is made. 


\section{First meeting and first assignment}

When I entered the classroom for our first meeting the students were seated facing the chalkboard. I instructed them to organize the chairs into a circle. These were third-year engineering students and they were not used to this kind of seating arrangement. Naturally, they were a bit puzzled. Then I handed them their first assignment:

Provide six Ghanaian proverbs with a materials connection. For each proverb,

(a) Give the rendition in the relevant Ghanaian language

(b) Indicate the language

(c) Provide an appropriate English translation

(d) Explain the meaning

(e) Discuss the materials connection

Required: A written report (750-1000 words) plus oral presentation.

For in-class practice, students were asked to provide some proverbs with materials connection. At first, nobody volunteered anything. They protested, "I don't know any proverbs," "I don't know how to write in my mother tongue." I provided an example: "Dade bi twa dade bi mu" (Akan, iron sharpens iron), and asked them to discuss the materials implication. The first suggestion from the students was that this proverb points to the superiority of one material over another, in this case, concerning mechanical properties. On further discussion another student offered that the proverb illustrates the need for collaboration; if a knife wants to be sharper, it needs the help of another material.

To the students who claimed that they knew no African proverbs, I challenged them to reflect on the fact that they are engineers. They are being trained at the university to solve problems. How can they solve their problem of proverbial ignorance? The suggestions that came out of our ensuing discussion included the following: they can ask parents and friends, and they can check if the library has books on proverbs.

\section{Second class meeting}

In the next class meeting (the following week) the students provided some feedback on the assignment. Their comments included such statements as:

My parents/friends were surprised. They thought the assignment was strange. They asked, "Is this really an engineering course? It sounds more like a course in African Studies." 
Osseo-Asare, K. /Legon Journal of the Humanities Vol. 30.1 (2019)

Here we see that the students could not imagine that a proverb could serve as a pedagogical tool in engineering. Yet, as Achebe has noted, in Igbo (African) culture "proverbs are the palm-oil with which words are eaten" (Achebe, 1958). Thus, it cannot be assumed that the engineers of traditional societies would have found proverbial language to be incompatible with engineering imagination and practice. Still, a relevant question remains: Do proverbs have any utility beyond the world of the ancestral engineers?

Below are a few of the proverbs they provided, as they continued to work on their assignment:

"Dze mekafua edokui o" - Ewe. Salt does not praise itself.

"Edon a cho apae no, ennyegye yie" - Akan. A cracked bell can never sound well.

"Gya ne atuduro nna faako" - Akan. Fire and gunpowder do not sleep together.

"Enam dua so na ahoma hunu soro" - Akan. It is through the tree that the vine sees the sky (i.e., climbs up).

In the examples above, the requirement that the proverbs should have "a materials connection" was taken to mean that the proverb must explicitly refer to a "material." Thus, based on the definition of a material as a "solid with useful structural, electrical (including electronic or magnetic), optical, or corrosion-resistance properties" (Evans and De Jonghe, 1991), the relevant materials or materials-based articles in the above proverbs were salt (sodium chloride, $\mathrm{NaCl}$ ), a bell (made of metal), gunpowder (nitrocellulose formulations), vine/tree (cellulosic biomaterials).

\section{Reports}

Table 1 presents a collection of proverbs taken from reports submitted by the students in response to the assignment previously described above. Clearly, once the students got over their initial fears and passivity, including the previously noted misconception that engineering and proverbial wisdom were incompatible, they were able to find sources for relevant proverbs. Regarding parts (a), (b), and (c) of the assignment, it can be seen from the table that all the proverbs submitted mentioned at least one materialsrelated item. These items are collected in Table 2; the most common was tree (wood) with seven mentions, metallic items were next with four citations (bell, gold, sword, and gong-gong). The multiple appearances of tree (wood) perhaps reflects the fact that the elders who first formulated the proverbs 
lived close to nature. Overall, the explanations given for the proverbs (part (d)) were reasonable, as further discussed below.

Part (e) of the assignment requested students to explicate the connection of their proverbs to materials science and engineering. In Table 1 the word "material (s)" appeared explicitly, at least once, in nine of the entries in the column under "(e) Materials Connection". Adding to this, related terms, like "metals", "alloy", "mineral", "vellum" (of a drum), and "gong-gong", makes it fourteen. In Table 3 these fourteen responses to part (e), designated as Group A, are deconstructed by tracking relevant keywords found in parts (a) - (e). The remaining responses (i.e., those missing "materials" or materials-related terms in part (e)), designated as Group B, are also deconstructed, as shown in Table 4.

This section of the assignment was a call to the students to relate their proverbs to one or more of the four legs of MSE. Inspection of Table 3 reveals that, on the whole, the students put in a good effort to respond to this challenge. In Proverb No. 1, for example, the underlying thought processes can be traced along the sequence: $(\mathrm{a}, \mathrm{b})$ dua/bo/twa $\rightarrow$ (c) tree/rock/cut $\rightarrow$ (d) you/close friend/rebuke $\rightarrow$ (e) silver/gold/select (do not reject). Gold (e) represents the rock (c) or close friend (d) that is difficult to reject because of its attractive (superior) materials properties (purity, chemical stability).

In almost all the entries in Table 3, the logic in the proverb is transferred to materials science and engineering in the form of a rule linking two or more of the four legs of MSE. In Proverb No. 3, for instance, the collaboration between the tree and the vine is transferred to that between two metals that combine to form an alloy with desired properties. In Proverb No. 10, the observation that certain changes are impossible (e.g., the transformation of a log in water into a turtle) is used to teach us that inappropriate processing protocols can never yield us materials with the desired structures and properties. It is interesting to note that Proverb No. 15 departs from this principle. Here, the relationship is reversed: materials properties are used as a vehicle for social commentary. It is the government itself that has instituted an opportunity for dialogue (People's Assembly). Therefore, there is no need to be hesitant (do not beat the side of the drum). Rather, take full advantage of this opportunity (strike the vellum of the drum). Proverb No. 12 reminds us that the fundamental value of a material is found in its properties and performance and not in public relations. This insight is then extended to the relationship between scientific discovery and the inventor: the discovery speaks for itself. 
In contrast to the above, the submissions presented in Table 4 reveal a break in the chain of the thinking process on going from Meaning (d) to Materials Connection (e). Referring to Proverb No. 2, for instance, it can be seen that the statement provided under Materials Connection is more about natural resource development than on any of the four legs of MSE. In the case of Proverb No. 8, the focus in part (e) is on scientific methodology, not on materials. Proverb No. 13 is applied to floods, erosion, and afforestation, as well as girl-child education, but not to materials science and engineering. Finally, Proverb No. 14 is directed to malaria eradication.

The assignment challenged the students' grasp of the technical meaning of the term "material" and the associated group discussions encouraged them to link concepts and definitions to the environment around them and their everyday experiences. Thus, in Proverb No. 7 the following statement appears under column (e): "we cannot have these two above mentioned materials coming together anywhere without a deflagration". Given the context, the two materials refer to fire and gunpowder. This statement, therefore, provides an opportunity to ask and discuss the question, "is fire a material"? Proverb No. 12 refers to common salt as a "mineral". This can instigate an interesting conversation about the relationship between a "mineral" and a "material." Also, it is interesting to note for this proverb that when students cite inventors, they refer to non-African personalities of the past, i.e., Isaac Newton and James Watt (see Table 1). There is an opportunity here to encourage students to search for African inventors. For example, they may never have heard of the Ghanaian Victor Lawrence, whose pioneering inventions have led to major advances in today's electronic data communications (National Science Foundation, n.d.; The History Makers, n.d.). Proverb No. 16 mentions "mineral resources" and links them to "raw materials," and bemoans the fact that these are mostly exported without processing. Here, one may reflect on the relationship between "raw materials" and "engineered materials."

\section{Indirection}

In African societies proverbs serve as rhetorical devices which help to minimize conflict in face-to-face discourse (Yankah, 1989). Quick reactions are frustrated and possible confrontations are softened when one has to pause to decipher the hidden meaning embedded in a statement that is not expressed in direct everyday language. Often the indirection is further enriched by the multiple meanings that may be associated with a given statement. 
In science and engineering pedagogy this same proverbial indirection can serve as a powerful tool for probing hidden meanings and identifying novel connections. As an illustration, consider Proverb No. 9, "Sika ano yenam sen sekan." It is possible that, as originally deployed, this proverb involved a play on the words "sika" and "sekan." And sekan (knife) too could be a placeholder for afena (sword). Further, if we consider the fact that in the original context "sika", translated here as "money", probably referred to "gold dust", then this proverb may be inviting us to also consider the scientific observation that gold, in the form of unaggregated particles (dust) cannot display the mechanical sharpness offered by a massive piece of metal shaped into a knife (or sword). However, here, the elders' use of the word "sharp" may depart from everyday usage. They may be alluding to the social function of gold (money, wealth); that is, the observation that financial or economic power may be sharper (leading to conquest of nations) than military power (the knife, the sword).

Indirection frees us to direct the proverb where we want it. For example, with Proverb No. 10, we may choose to focus on the log, the water, the turtle (crocodile), or the immersion time. Thus, provided with a given starting material (log), we may be advised to face the reality that a desired product material (turtle or crocodile) will elude us so long as we choose the wrong processing conditions (water, and immersion time). On the other hand, the admonition may be intended to alert us to the fact that if we desire a particular product material (turtle or crocodile), then the starting material (log) must be selected with care.

The freedom offered by indirection can also stimulate serious scientific discussion. Regarding Proverb No. 8, we may reflect on the question: why does the cracked bell produce a dull sound compared with the undamaged bell? What is sound? How does it travel in a material, and why do the damaged and whole bells respond differently? What are the relevant materials (micro)structures? The statement "each single process is crucial to the ultimate target" also calls for further elaboration and this would require explicit consideration of specific challenges in materials processing.

In regard to Proverb No. 9 we may ask the question: How can one turn a metal powder into a massive piece of metal? For two proverbs the materials connection mentioned alloys (Nos. 3,6). Here is an opportunity to consider some of the enhanced properties that result when two or more metals are combined to produce an alloy. What new microstructures result and how are these related to the enhanced new properties? 


\section{Conclusion}

As noted above, the immediate reactions of students to the assignment was that of puzzlement and self-distancing. They had been pre-programmed to see engineering as an alien system of expertise that is disconnected from their own culture and environment. The seventeen proverbs collected in Table 1 demonstrate, however, that students were able to overcome their initial fear and disengagement.

The assignment took them outside of their comfort zone. They came face to face with the fact that knowing how to take the first step is a critical component of engineering problem solving. If you do not know any African proverbs, how should you proceed to work on the assignment? They learned that a question may serve as the first step in discovering the answer. They were used to receiving questions from instructors, but they were less practiced in posing questions to themselves. They discovered that "I don't know any proverbs" should lead to "Where/how can I discover some appropriate proverbs?"

Going from part (d) to part (e) of the assignment posed a major challenge to students. They could retrieve a proverb from a book, friend, or relative. But how to operationalize the request for the "materials connection"? This had to come out of their own reflections. They had to ponder the questions: "What is a 'material'?", "what is meant by 'materials science and engineering'?", and "how should one understand the term 'materials connection'?" In the context of the course "materials connection" required that students pay attention to the technical meaning of the discipline of materials science and engineering. Accordingly, ideally the sought-after connection must be understood in terms of the relationship of the proverb to one or more of the four MSE legs, i.e., processing, structure, properties, and performance.

The method of deconstruction introduced in this paper was helpful in tracing students' reasoning. The linkages were clear and successful when students were able to transfer the logic of the proverb to one or more of the MSE legs. When this transfer was loose, students tendered to wander into important but not immediately relevant areas, such as natural resource development, scientific methodology, natural disasters, environmental rehabilitation, girl-child education, and public health challenges.

The unsuccessful "linkages" were nonetheless instructive. They demonstrated that the assignment challenged students to reflect on the world 
around them, including the associated socioeconomic challenges. Further, their answers illustrated the power of indirection in proverbial discourse. A given proverb is capable of addressing multiple issues. Thus, while the focus in this paper was on materials science and engineering, it may be concluded that other engineering disciplines, such as mechanical, electrical, civil, and biomedical engineering may also provide useful opportunities for extending this approach to engineering pedagogy. Certainly, the deconstruction methodology introduced in this paper should be readily transferable to other (engineering) disciplines. And regarding sources of African proverbs, future students who plead "I do not know African proverbs" deserve no sympathy. Several collections of African proverbs are now available in books and online (Akporobaro and Emovon, 1994; Akrofi, 1958; Amadiume, 1994, 1995; Ampem, 1999; Appiah et al., 2007; Asante, 2002; Bangnikon, 1999; Dzobo, 1997; Nkansah-Kyeremateng, 2000; Knappert, 1997; Yankah, 2012).

\section{Acknowledgements}

I thank Samuel Kofi Sefa-Dedeh, the founding Dean for inviting me to spend a sabbatical semester at the then three-year-old School of Engineering Sciences at the University of Ghana. It was fun spending time with my students in the Materials and the Future course. I thank them for going with the flow and allowing me to test out the ideas reported in this paper. Without their cooperation I would not have had this opportunity to experiment this way with African proverbs. I thank my colleagues Lucas Damoah and Yaw Bensah, founding faculty of the Materials Science and Engineering department, and Titus Ofei, my able teaching assistant, for their friendship and enthusiastic support of this experiment. Sarah-Lynn Ainsaa Nuno Mansaray deserves thanks for helpful conversations and assistance with Ga translation. I thank Fran Osseo-Asare for her support and encouragement. Her original purchase of Bu Me Be (Appiah et al., 2007) helped inspire this approach to engineering pedagogy. The many stimulating discussions with her plus her editorial comments were invaluable. Finally, I thank the referees for their questions and suggestions which have helped to strengthen this paper. 


\section{References}

Achebe, C. (1958). Things Fall Apart. London, UK: Heinemann.

Akporobaro, F. B. O. and Emovon, J. A. (1994). Nigerian Proverbs:

Meanings and Relevance Today. Lagos, Nigeria: Nigeria Magazine Publication.

Akrofi, C.A. (1958). Twi Mmebuscm. Twi Proverbs, London, UK: Macmillan. Amadiume, C. S. (1994). Ilu Ndi Igbo: A Study of Igbo Proverbs, Vol. 1. Enugu, Nigeria: Fourth Dimension Publishing Co.

Amadiume, C. S. (1995). Ilu Ndi Igbo: A Study of Igbo Proverbs, Vol. 2. Enugu, Nigeria: Fourth Dimension Publishing Co.

Ampem, A. A. G. (1999). Akan Mmebuscm Bi. Akan Proverbs in Akan and English. Kumasi, Ghana: University Press.

Appiah, P., Appiah, K. A., and Agyeman-Duah, I. (2007). Bu Me Be. Proverbs of the Akans. Banbury, UK: Ayebia Clarke.

Asante, E. K. A. (2002). Akan Proverbs. Their Origins, Meanings and Symbolical Representations in Ghanaian Material Cultural Heritage. Accra, Ghana: Asempa Publishers.

Bangnikon, L. D. (1999). Wisdom to Guide You. A Book of Dagara Proverbs, Wisdom and Humour. Tamale, Ghana: Luke D. Bangnikon.

Callister, Jr., W. D. and Rethwisch, D. G. (2014). Materials Science and Engineering. An Introduction, $9^{\text {th }}$ Ed. New York, NY: Wiley.

Dzobo, N. K. (1997). African Proverbs. The Moral Value of Eve Proverbs. Accra, Ghana: Bureau of Ghana Languages.

Essegbey, G. (2006). A Science Culture is Key to Ghana's Development. SciDev.Net, Nov. 29; https://www.scidev.net/global/capacitybuilding/opinion/a-science-culture-is-key-to- ghanas- development. html.

Evans, J. W. and De Jonghe, L. C. (1991). The Production of Inorganic Materials. New York, NY: Macmillan.

National Academy of Engineering (n.d.). Dr. Victor B. Lawrence, Member. https://www.nae.edu/30767/Dr-Victor-B-Lawrence.

Nkansah-Kyeremateng, K. (2000). Akanfor Mmebuscm Bi. Some Akan Proverbs. Accra, Ghana: Sebewie Publishers.

Knappert, J. (1997). Swahili Proverbs. Burlington, VT: Univ. of Vermont. The History Makers (n.d.). Victor Lawrence. https://www.thehistorymakers. org/biography/victor-lawrence. 
Osseo-Asare, K. /Ogya ne atuduro nna faako - Fire and gunpowder do not sleep together

Thrower, P. A. (1991). Materials in Today's World, $2^{\text {nd }}$. Ed. New York, NY: McGraw-Hill.

Yankah, K. (2012). The Proverb in the Context of Akan Rhetoric, $2^{\text {nd }}$. Ed. New York, NY: Diasporic Africa Press.

Yankah, K. (1989). Proverbs: The Aesthetics of Traditional Communication. Research in African Literatures, 20(3), 325-346. 


\section{Appendix}

Table 1: Proverbs and Materials Science and Engineering

\begin{tabular}{|c|c|c|c|c|}
\hline $\begin{array}{l}\text { Ghanaian } \\
\text { Proverb }\end{array}$ & Language & $\begin{array}{l}\text { English Trans- } \\
\text { lation }\end{array}$ & Meaning & Materials Connection \\
\hline $\begin{array}{l}\text { 1. Dua bata bo } \\
\text { a, ne twa ye } \\
\text { twana }\end{array}$ & Twi & $\begin{array}{l}\text { It is difficult to } \\
\text { cut (chop down) } \\
\text { a tree that is } \\
\text { close to a rock }\end{array}$ & $\begin{array}{l}\text { It is difficult to take } \\
\text { a firm decision or } \\
\text { rebuke a family } \\
\text { member or close } \\
\text { friend when he or } \\
\text { she offends you }\end{array}$ & $\begin{array}{l}\text { Considering two metals, } \\
\text { e.g., gold and silver in } \\
\text { jewelry production, } \\
\text { gold is chosen because } \\
\text { of its pureness even if } \\
\text { it is available in smaller } \\
\text { quantity }\end{array}$ \\
\hline $\begin{array}{l}\text { 2. Aboa bi beka } \\
\text { wo a, na } \varepsilon f i r i \\
\text { wo ntoma mu }\end{array}$ & Twi & $\begin{array}{l}\text { If an insect will } \\
\text { bite you then } \\
\text { it will be from } \\
\text { your cloth }\end{array}$ & $\begin{array}{l}\text { If someone can } \\
\text { harm you, then it is } \\
\text { probably a person } \\
\text { already around you }\end{array}$ & $\begin{array}{l}\text { If any group of people } \\
\text { would want to develop } \\
\text { their environment, they } \\
\text { should consider first } \\
\text { exploiting their natural } \\
\text { resources, rather than } \\
\text { thinking that the basic } \\
\text { requirements for their } \\
\text { development are found } \\
\text { in other countries from } \\
\text { which they have to im- } \\
\text { port things. }\end{array}$ \\
\hline $\begin{array}{l}\text { 3. Enam dua } \\
\text { so na ahoma } \\
\text { hunu soro }\end{array}$ & Twi & $\begin{array}{l}\text { It is through } \\
\text { the tree that the } \\
\text { vine climbs up } \\
\text { (sees the sky) }\end{array}$ & $\begin{array}{l}\text { You can become a } \\
\text { great person with } \\
\text { the help of another }\end{array}$ & $\begin{array}{l}\text { To produce an alloy, e.g., } \\
\text { brass, two metals - cop- } \\
\text { per and zinc are mixed } \\
\text { together to obtain the } \\
\text { required properties. }\end{array}$ \\
\hline $\begin{array}{l}\text { 4. Woforo duapa } \\
\text { a, na yepia wo }\end{array}$ & Twi & $\begin{array}{l}\text { It is only when } \\
\text { you are climbing } \\
\text { a good tree that } \\
\text { you receive help }\end{array}$ & $\begin{array}{l}\text { It is only through } \\
\text { leading a good life } \\
\text { that when you need } \\
\text { help to go further } \\
\text { you are granted it. }\end{array}$ & $\begin{array}{l}\text { Any material that does } \\
\text { not prove to conform to } \\
\text { the specifications that } \\
\text { you have set for a par- } \\
\text { ticular job should simply } \\
\text { be discarded, while the } \\
\text { potential materials for } \\
\text { the desired need are } \\
\text { given the necessary con- } \\
\text { sideration. }\end{array}$ \\
\hline $\begin{array}{l}\text { 5. Dua a Ananse } \\
\text { adi awuo } \\
\text { no, Ntikuma } \\
\text { ntena asee nto } \\
\text { nko }\end{array}$ & Twi & $\begin{array}{l}\text { Ntikuma } \\
\text { (son of Ananse) } \\
\text { is not supposed } \\
\text { to sit under a } \\
\text { tree that has } \\
\text { killed his father } \\
\text { and doze off }\end{array}$ & $\begin{array}{l}\text { You do not repeat } \\
\text { an event that has } \\
\text { landed another } \\
\text { person in trouble. }\end{array}$ & $\begin{array}{l}\text { All materials, in spite of } \\
\text { their individual differ- } \\
\text { ences, can be categorized } \\
\text { into various classes and, } \\
\text { therefore, there are some } \\
\text { qualities that may be } \\
\text { common. Thus, when } \\
\text { treating such materials, } \\
\text { temperatures, pressures } \\
\text { and other variables that } \\
\text { are known to be un- } \\
\text { favorable to that class } \\
\text { of materials should be } \\
\text { looked at with care. }\end{array}$ \\
\hline
\end{tabular}


Osseo-Asare, K. /Ogya ne atuduro nna faako - Fire and gunpowder do not sleep together

\begin{tabular}{|c|c|c|c|c|}
\hline $\begin{array}{l}\text { 6. Ekaa dee onni } \\
\text { ntoma nko } \\
\text { a, anka daa } \\
\text { yegoro asafo }\end{array}$ & Twi & \begin{tabular}{|l|} 
To the one \\
without a cloth, \\
asafo - a dance \\
performed \\
without cloth - is \\
always preferred
\end{tabular} & $\begin{array}{l}\text { This proverb } \\
\text { frowns on laziness } \\
\text { and encourages } \\
\text { hard work so as } \\
\text { to achieve greater } \\
\text { heights in life. }\end{array}$ & $\begin{array}{l}\text { A blacksmith cannot ob- } \\
\text { tain good bronze without } \\
\text { first taking the properties } \\
\text { of tin and copper into } \\
\text { consideration. The ma- } \\
\text { terials engineer is always } \\
\text { interested in knowing the } \\
\text { possibility of putting the } \\
\text { materials he/she comes } \\
\text { across into good use } \\
\text { while probably for his/ } \\
\text { her counterparts from } \\
\text { other disciplines this may } \\
\text { not be of much interest. }\end{array}$ \\
\hline $\begin{array}{l}\text { 7. Gya ne atudu- } \\
\text { ro nna faako }\end{array}$ & Twi & $\begin{array}{l}\text { Fire and gun- } \\
\text { powder do not } \\
\text { sleep together }\end{array}$ & $\begin{array}{l}\text { For peace of mind } \\
\text { certain things are } \\
\text { best left far apart }\end{array}$ & $\begin{array}{l}\text { In science, we know that } \\
\text { because of the chemical } \\
\text { compositions of some } \\
\text { materials we should keep } \\
\text { them apart unless we } \\
\text { want to generate a cer- } \\
\text { tain desired effect from } \\
\text { their coming together. } \\
\text { For instance, we cannot } \\
\text { have these two above } \\
\text { mentioned materials } \\
\text { coming together any- } \\
\text { where without a deflagra- } \\
\text { tion or fire outbreak. }\end{array}$ \\
\hline $\begin{array}{l}\text { 8. Edon a cho } \\
\text { apae no } \varepsilon n n y- \\
\text { egye yie }\end{array}$ & Twi & $\begin{array}{l}\text { A cracked bell } \\
\text { can never sound } \\
\text { well }\end{array}$ & $\begin{array}{l}\text { When something } \\
\text { is damaged it will } \\
\text { never give the } \\
\text { expected output } \\
\text { (unless it is fixed) }\end{array}$ & $\begin{array}{l}\text { In science, great atten- } \\
\text { tion is given to detail, } \\
\text { each single process is } \\
\text { crucial to the ultimate } \\
\text { target. Any science pro- } \\
\text { ject pursued outside the } \\
\text { systematic methodology } \\
\text { would lead to failure or } \\
\text { even catastrophe in some } \\
\text { instances. }\end{array}$ \\
\hline $\begin{array}{l}\text { 9. Sika ano } \\
\text { yenam sen } \\
\text { sekan (afena) }\end{array}$ & Twi & $\begin{array}{l}\text { Money (gold) is } \\
\text { sharper than the } \\
\text { knife (sword) }\end{array}$ & $\begin{array}{l}\text { Money commands } \\
\text { more authority } \\
\text { than the sword. }\end{array}$ & $\begin{array}{l}\text { In materials science, } \\
\text { certain materials become } \\
\text { more powerful than they } \\
\text { originally were when } \\
\text { value is added. Money is } \\
\text { made from mere paper } \\
\text { whereas swords are } \\
\text { made from strong metals } \\
\text { but money commands } \\
\text { so much more than the } \\
\text { sword could ever possi- } \\
\text { bly command. }\end{array}$ \\
\hline
\end{tabular}


Osseo-Asare, K. /Legon Journal of the Humanities Vol. 30.1 (2019)

\begin{tabular}{|c|c|c|c|c|}
\hline 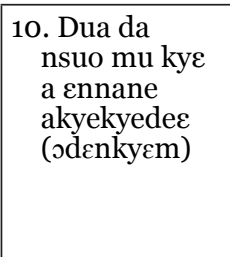 & Twi & $\begin{array}{l}\text { When a log lies } \\
\text { in water for } \\
\text { a long time it } \\
\text { doesn't become } \\
\text { a turtle (croco- } \\
\text { dile) }\end{array}$ & $\begin{array}{l}\text { Certain changes or } \\
\text { events are simply } \\
\text { impossible. }\end{array}$ & $\begin{array}{l}\text { The chemical composi- } \\
\text { tion of some materials } \\
\text { makes them unsuited } \\
\text { for certain applications. } \\
\text { That is, certain things are } \\
\text { scientifically impossible } \\
\text { because they defy scien- } \\
\text { tific laws and principles. }\end{array}$ \\
\hline $\begin{array}{l}\text { 11. Dua a egya } \\
\text { anya aka ano } \\
\text { no, ne so nye } \\
\text { den }\end{array}$ & Twi & $\begin{array}{l}\text { Wood that is } \\
\text { already touched } \\
\text { by fire isn't hard } \\
\text { to set alight. }\end{array}$ & $\begin{array}{l}\text { When someone } \\
\text { already has some } \\
\text { knowledge, skill or } \\
\text { experience perti- } \\
\text { nent to a problem, } \\
\text { it is easy to get } \\
\text { him/her to provide } \\
\text { help when needed. }\end{array}$ & $\begin{array}{l}\text { Because some materi- } \\
\text { als have certain unique } \\
\text { properties, it is easy to } \\
\text { get them to do particular } \\
\text { things we desire. For in- } \\
\text { stance, metals have high } \\
\text { thermal conductivity. Be- } \\
\text { cause mercury is metallic } \\
\text { and fluid it is a useful } \\
\text { material for temperature } \\
\text { measurements. }\end{array}$ \\
\hline $\begin{array}{l}\text { 12. Dze } \\
\text { mekafua edokui } \\
\quad \text { o }\end{array}$ & Ewe & $\begin{array}{l}\text { Salt does not } \\
\text { praise itself. }\end{array}$ & \begin{tabular}{|l} 
One must not \\
boast of his or her \\
good qualities but \\
should allow other \\
people to see and \\
talk about them
\end{tabular} & $\begin{array}{l}\text { Common salt forms an } \\
\text { important mineral in our } \\
\text { diets. It adds flavor and } \\
\text { is used for food preserva- } \\
\text { tion. The diverse uses of } \\
\text { this vital mineral render } \\
\text { it an essential part of life } \\
\text { and make it impossible } \\
\text { for people to deny its } \\
\text { importance and good } \\
\text { qualities. } \\
\text { Inventors such as Isaac } \\
\text { Newton, James Watt and } \\
\text { other scientists of ancient } \\
\text { times can be viewed as } \\
\text { the salts of their times } \\
\text { as well as generations to } \\
\text { come. These people are } \\
\text { remembered today, not } \\
\text { because of their words } \\
\text { of self-exaltation but } \\
\text { because of their great } \\
\text { contribution to science } \\
\text { and technology. }\end{array}$ \\
\hline
\end{tabular}


Osseo-Asare, K. /Ogya ne atuduro nna faako - Fire and gunpowder do not sleep together

\begin{tabular}{|c|c|c|c|c|}
\hline $\begin{array}{l}\text { 13. Te ni tsut- } \\
\text { swaloi le tse } \\
\text { efo le tso konn } \\
\text { te }\end{array}$ & $\mathrm{Ga}$ & $\begin{array}{l}\text { The stone that } \\
\text { the builders } \\
\text { passed over } \\
\text { became a rock in } \\
\text { the deep forest }\end{array}$ & $\begin{array}{l}\text { Something that } \\
\text { one views as less } \\
\text { important, can } \\
\text { become the most } \\
\text { valuable thing in } \\
\text { future }\end{array}$ & $\begin{array}{l}\text { In the olden days, invest- } \\
\text { ing in girl-child edu- } \\
\text { cation was viewed as a } \\
\text { waste of resources since } \\
\text { most of the girls grew up } \\
\text { to be housewives. How- } \\
\text { ever, society is dynamic } \\
\text { and with the recent surge } \\
\text { of dual income earning to } \\
\text { ensure a good standard } \\
\text { of living in most homes, } \\
\text { girl-child education has } \\
\text { become a necessity. In } \\
\text { addition, girl-child ed- } \\
\text { ucation has encouraged } \\
\text { gender balance in our } \\
\text { society, and females are } \\
\text { now given opportunities } \\
\text { to venture into areas } \\
\text { which were otherwise } \\
\text { unavailable to them in } \\
\text { the past. This has given } \\
\text { rise to renowned female } \\
\text { leaders such as Ellen } \\
\text { Johnson Sirleaf (former } \\
\text { President of Liberia), } \\
\text { Condoleezza Rice } \\
\text { (former U.S Secretary } \\
\text { of State), Joyce Aryee } \\
\text { (former CEO of Ghana } \\
\text { Chamber of Mines), } \\
\text { among others. } \\
\text { Thus, girl-child educa- } \\
\text { tion which was some- } \\
\text { what rejected in the past } \\
\text { has become very valuable } \\
\text { in our present society. }\end{array}$ \\
\hline
\end{tabular}


Osseo-Asare, K. /Legon Journal of the Humanities Vol. 30.1 (2019)

\begin{tabular}{|l|l|l|l|}
\hline $\begin{array}{l}\text { 14. Keji tso kome } \\
\text { kpee kosys le } \\
\text { ekus }\end{array}$ & $\begin{array}{l}\text { Ga } \\
\text { tree encounters } \\
\text { strong wind, it } \\
\text { breaks }\end{array}$ & $\begin{array}{l}\text { Unity is strength or } \\
\text { a given task is most } \\
\text { successful when } \\
\text { it is shared with } \\
\text { others }\end{array}$ & $\begin{array}{l}\text { Considering the recent } \\
\text { malaria prevention } \\
\text { program introduced } \\
\text { in Ghana, it may be } \\
\text { difficult to complete the } \\
\text { program by Ghanaians } \\
\text { alone. It therefore calls } \\
\text { for Ghana to collaborate } \\
\text { with other countries or } \\
\text { donors to pool resources } \\
\text { to enable the program to } \\
\text { be carried out success- } \\
\text { fully. An example of } \\
\text { the positive outcome of } \\
\text { such collaboration is the } \\
\text { donation made by the US } \\
\text { in support of the malaria } \\
\text { prevention program. } \\
\text { Although Ghana could } \\
\text { have acquired this money } \\
\text { over a period, sharing the } \\
\text { responsibility with other } \\
\text { countries makes it faster } \\
\text { and relatively easier to } \\
\text { complete the program. } \\
\text { In addition, most floods } \\
\text { and erosion can be } \\
\text { prevented by embarking } \\
\text { on afforestation pro- } \\
\text { grams. Thus, planting an } \\
\text { adequate number of trees } \\
\text { will serve as windbreaks } \\
\text { to control erosion }\end{array}$ \\
\hline
\end{tabular}


Osseo-Asare, K. /Ogya ne atuduro nna faako - Fire and gunpowder do not sleep together

\begin{tabular}{|c|c|c|c|c|}
\hline $\begin{array}{l}\text { 15. Twene } \\
\text { anim da ho a, } \\
\text { yemmo nkyen }\end{array}$ & Twi & $\begin{array}{l}\text { Do not hit the } \\
\text { side of the drum } \\
\text { when the vellum } \\
\text { is available }\end{array}$ & $\begin{array}{l}\text { Do not be afraid } \\
\text { to point out the } \\
\text { mistakes of others } \\
\text { or tell a person } \\
\text { that he/she is at } \\
\text { fault when he/she } \\
\text { truly is. }\end{array}$ & $\begin{array}{l}\text { When the vellum of a } \\
\text { drum is struck, the sound } \\
\text { produced is better than } \\
\text { that produced by striking } \\
\text { the side. Therefore, when } \\
\text { people of a nation learn } \\
\text { to put forward construc- } \\
\text { tive criticisms, efficient } \\
\text { results are obtained to } \\
\text { enhance nation building. } \\
\text { For instance, the gov- } \\
\text { ernment in an attempt } \\
\text { to enable the people of } \\
\text { Ghana assess and com- } \\
\text { mend the government or } \\
\text { bring out their grievances } \\
\text { to be addressed by the } \\
\text { appropriate authorities } \\
\text { introduced the "People's } \\
\text { Assembly". Therefore, if } \\
\text { one is given such a rare } \\
\text { opportunity to point } \\
\text { out the mistakes of the } \\
\text { government or offer } \\
\text { constructive criticism } \\
\text { for nation building and } \\
\text { one abuses it by beat- } \\
\text { ing about the bush, or } \\
\text { refuses to point out the } \\
\text { mistakes due to fear, the } \\
\text { desired result may not be } \\
\text { achieved and national de- } \\
\text { velopment may be halted. }\end{array}$ \\
\hline $\begin{array}{l}\text { 16. Se biribi } \\
\text { ankoka mpepa a, } \\
\varepsilon \text { nnye kyered } \varepsilon\end{array}$ & Twi & $\begin{array}{l}\text { If nothing dis- } \\
\text { turbs the palm } \\
\text { frond, it does } \\
\text { not make noise }\end{array}$ & $\begin{array}{l}\text { Everything hap- } \\
\text { pens for a reason } \\
\text { or nobody takes an } \\
\text { action without a } \\
\text { cause to do so. }\end{array}$ & $\begin{array}{l}\text { Due to the lack of the } \\
\text { requisite technology, } \\
\text { Ghana is forced to export } \\
\text { important mineral re- } \\
\text { sources, such as bauxite } \\
\text { to foreign countries to be } \\
\text { processed into alumina, } \\
\text { which is later used in the } \\
\text { production of aluminum } \\
\text { products. If Ghana had } \\
\text { the means to process the } \\
\text { available raw materials } \\
\text { without relying on for- } \\
\text { eign countries, exporta- } \\
\text { tion of the raw materials } \\
\text { would be avoided and the } \\
\text { money gained might be } \\
\text { used for other develop- } \\
\text { mental projects. }\end{array}$ \\
\hline
\end{tabular}


Osseo-Asare, K. /Legon Journal of the Humanities Vol. 30.1 (2019)

\begin{tabular}{|l|l|l|l|}
\hline $\begin{array}{l}\text { 17. Dawuro mpo } \\
\text { yeamene na } \\
\text { Enye n'abaa }\end{array}$ & $\begin{array}{l}\text { Twi } \\
\text { gong has been } \\
\text { swallowed how } \\
\text { much more its } \\
\text { stick }\end{array}$ & $\begin{array}{l}\text { When one over- } \\
\text { comes a great } \\
\text { obstacle, one is } \\
\text { poised to overcome } \\
\text { relatively minor } \\
\text { ones. }\end{array}$ & $\begin{array}{l}\text { The design of the gong- } \\
\text { gong is more complex } \\
\text { than the stick used in } \\
\text { striking it. In addition, } \\
\text { the gong-gong is bigger } \\
\text { and heavier than its } \\
\text { stick. Therefore, if one } \\
\text { encounters a difficult } \\
\text { situation and overcomes } \\
\text { it successfully, one is able } \\
\text { to tackle and overcome } \\
\text { less-challenging events. } \\
\text { Some foreign countries } \\
\text { are able to process raw } \\
\text { materials to produce } \\
\text { heavy machines for } \\
\text { industrial use. Therefore, } \\
\text { if Ghana should advance } \\
\text { in technology enough } \\
\text { to begin manufacturing } \\
\text { industrial equipment } \\
\text { and other challenging } \\
\text { products, such as com- } \\
\text { puters and airplanes as } \\
\text { well as training people } \\
\text { to manage our resources } \\
\text { efficiently, it will get to } \\
\text { a time when nothing } \\
\text { will seem impossible for } \\
\text { Ghanaians to do. }\end{array}$ \\
& &
\end{tabular}

Table 2: Materials-related terms found in submitted proverbs

\begin{tabular}{|l|l|l|l|}
\hline $\begin{array}{l}\text { Proverb } \\
\text { No. }\end{array}$ & $\begin{array}{l}\text { Material/Material-re- } \\
\text { lated Entity }\end{array}$ & $\begin{array}{l}\text { Proverb } \\
\text { No. }\end{array}$ & $\begin{array}{l}\text { Material/Material-related En- } \\
\text { tity }\end{array}$ \\
\hline 1 & Tree, rock & 10 & Wood (log), turtle \\
\hline 2 & Animal, cloth & 11 & Wood (log) \\
\hline 3 & Tree, vine & 12 & Salt \\
\hline 4 & Tree & 13 & Stone, cornerstone \\
\hline 5 & Tree & 14 & Tree \\
\hline 6 & Cloth & 15 & Drum (vellum, side) \\
\hline 7 & Gun powder & 16 & Palm frond \\
\hline 8 & Bell & 17 & Gong-gong, stick \\
\hline 9 & Gold (money), sword & & \\
\hline
\end{tabular}


Table 3: Deconstruction of students' discussion of materials connection (part (e) of assignment)

- Group A

\begin{tabular}{|c|c|c|}
\hline \begin{tabular}{|l|} 
Proverb \\
No. \\
\end{tabular} & Deconstruction (Keyword tracking) & Materials Connection \\
\hline 1 & $\begin{array}{l}\text { Dua/bo/twana } \rightarrow \text { tree/rock/difficult to cut } \\
\rightarrow \text { you/close friend/difficult to rebuke } \rightarrow \\
\text { silver/gold/difficult to reject }\end{array}$ & $\begin{array}{l}\text { Even if compared with silver, } \\
\text { only a small amount of gold is } \\
\text { available, it is still worth includ- } \\
\text { ing some gold in jewelry making, } \\
\text { because of the inherent purity of } \\
\text { this metal }\end{array}$ \\
\hline 3 & $\begin{array}{l}\text { Dua/ahoma/hunu soro } \rightarrow \text { tree/vine/climb } \\
\text { up } \rightarrow \text { another/you/attain greatness } \rightarrow \text { met- } \\
\text { al1/metal2/desired alloy }\end{array}$ & $\begin{array}{l}\text { Two metals (metal1 and metal2) } \\
\text { must be combined to produce an } \\
\text { alloy with the desired (enhanced) } \\
\text { properties. One metal helps the } \\
\text { other. }\end{array}$ \\
\hline 4 & $\begin{array}{l}\text { Wo/foro dua pa/ycpia wo } \rightarrow \text { you/climb good } \\
\text { tree/help (push) } \rightarrow \text { you/leading a good life/ } \\
\text { you receive help to go further } \rightarrow \text { material/ } \\
\text { exhibits desired properties/selected for task }\end{array}$ & $\begin{array}{l}\text { The material with the desired } \\
\text { properties (good tree) attracts } \\
\text { the most attention }\end{array}$ \\
\hline 5 & $\begin{array}{l}\text { Dua/Ananse adi awu/Ntikuma ntena ase } \varepsilon \\
\text { nto nko } \rightarrow \text { Tree/Ananse ate and died/Nti- } \\
\text { kuma should avoid dozing thereunder } \rightarrow \\
\text { An event/landed another person in trouble/ } \\
\text { you do not repeat } \rightarrow \text { environment (process, } \\
\text { service conditions)/detrimental/avoid }\end{array}$ & $\begin{array}{l}\text { Environmental, process, or } \\
\text { service conditions that are detri- } \\
\text { mental to the stability of a given } \\
\text { material (killed Ananse), should } \\
\text { be avoided }\end{array}$ \\
\hline 6 & $\begin{array}{l}\text { Ekaa de } \text { onni ntoma/yegoro asafo } \rightarrow \text { Left } \\
\text { to one without cloth/asafo dance preferred } \\
\rightarrow \text { the lazy/avoid hard work } \rightarrow \text { incompetent } \\
\text { materials engineer/cuts corners }\end{array}$ & $\begin{array}{l}\text { To prepare an alloy (a mixture of } \\
\text { metals) effectively (i.e., a product } \\
\text { with the desired properties and } \\
\text { performance), one cannot bypass } \\
\text { the need to consider the proper- } \\
\text { ties of the constituent metals (do } \\
\text { not choose the path of the asafo } \\
\text { dancer) }\end{array}$ \\
\hline 7 & $\begin{array}{l}\text { Gya/atuduro/nna faako } \rightarrow \text { fire/gunpowder/ } \\
\text { sleep not together } \rightarrow \text { certain things/with } \\
\text { potential antagonistic interactions/best left } \\
\text { apart } \rightarrow \text { external stimulus/material/may be } \\
\text { incompatible }\end{array}$ & $\begin{array}{l}\text { Materials properties drive mate- } \\
\text { rials performance. Select materi- } \\
\text { als with performance in mind }\end{array}$ \\
\hline 9 & $\begin{array}{l}\text { Sika/ano yenam/sekan (afena) } \rightarrow \text { Money } \\
\text { (Gold dust)/sharper/sword } \rightarrow \text { Money/ } \\
\text { greater authority/sword } \rightarrow \text { economic power } \\
\text { derived by value addition to materials/may } \\
\text { be more potent than/military power }\end{array}$ & $\begin{array}{l}\text { Gold (gold dust) is sharper than } \\
\text { the sword because it is valued } \\
\text { more by society. Thus, one mate- } \\
\text { rial may become more important } \\
\text { (sharper) than another, after } \\
\text { value addition (e.g., processing } \\
\text { leading to desirable properties/ } \\
\text { performance, or perceived great- } \\
\text { er economic value) }\end{array}$ \\
\hline
\end{tabular}


Osseo-Asare, K. /Legon Journal of the Humanities Vol. 30.1 (2019)

\begin{tabular}{|c|c|c|}
\hline 10 & 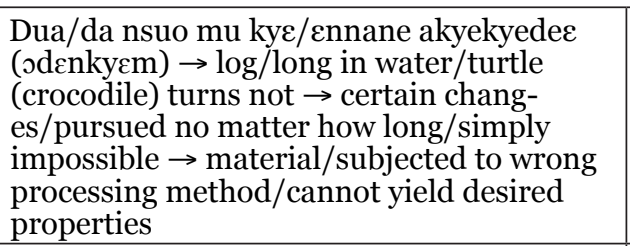 & $\begin{array}{l}\text { Conversion of a log into a turtle } \\
\text { or crocodile is impossible, no } \\
\text { matter the processing method } \\
\text { imposed. Similarly, some materi- } \\
\text { als are just not suited for certain } \\
\text { applications }\end{array}$ \\
\hline 11 & $\begin{array}{l}\text { Dua/egya anya aka ano/ne so nye den } \rightarrow \\
\text { Wood/already touched by fire/is easily set } \\
\text { ablaze } \rightarrow \text { someone/already endowed with } \\
\text { some skill/easy to help } \rightarrow \text { material/known } \\
\text { desirable properties/easily selected }\end{array}$ & $\begin{array}{l}\text { Materials with established unique } \\
\text { properties, can be readily select- } \\
\text { ed for certain desired applica- } \\
\text { tions (performance) }\end{array}$ \\
\hline 12 & $\begin{array}{l}\text { Dze/mekafua/edokui o } \rightarrow \text { Salt/does not } \\
\text { praise/itself } \rightarrow \text { One/must not boast/his } \\
\text { or her good qualities } \rightarrow \text { material/finds not } \\
\text { its value in sales pitches/but in superior } \\
\text { performance }\end{array}$ & $\begin{array}{l}\text { The value of a material is evident } \\
\text { in its properties and perfor- } \\
\text { mance, not in sales pitches or } \\
\text { advertisements }\end{array}$ \\
\hline 15 & $\begin{array}{l}\text { Twene/anim da ho a/yemmo nkyen } \rightarrow \text { The } \\
\text { vellum/is exposed/use not the side of the } \\
\text { drum } \rightarrow \text { A mistake/visible to all/no need to } \\
\text { fear pointing it out } \rightarrow \text { The People's Assem- } \\
\text { bly/available for citizens to offer construc- } \\
\text { tive criticisms/don't beat about the bush }\end{array}$ & $\begin{array}{l}\text { When the vellum of a drum is } \\
\text { struck, the sound produced is } \\
\text { better than that produced by } \\
\text { striking the side. Therefore, ... the } \\
\text { government in an attempt to en- } \\
\text { able the people of Ghana assess } \\
\text { and commend the government } \\
\text { or bring out their grievances to } \\
\text { be addressed by the appropriate } \\
\text { authorities introduced the "Peo- } \\
\text { ple's Assembly". Therefore, if one } \\
\text { is given such a rare opportunity } \\
\text { to point out the mistakes of the } \\
\text { government or offer constructive } \\
\text { criticism for nation building and } \\
\text { one abuses it by beating about } \\
\text { the bush or refuses to point out } \\
\text { the mistakes due to fear, the de- } \\
\text { sired result may not be achieved } \\
\text { and national development may } \\
\text { be halted. }\end{array}$ \\
\hline 16 & $\begin{array}{l}\text { Biribi ankoka mpepa/ } \text { ennye kyercde } \rightarrow \\
\text { nothing disturbs palm frond/noise is not } \\
\text { made } \rightarrow \text { no cause/no effect } \rightarrow \text { lack of } \\
\text { technology/nation cannot add value to raw } \\
\text { materials }\end{array}$ & $\begin{array}{l}\text { Without the appropriate industri- } \\
\text { al base, a nation ends up an ex- } \\
\text { porter of low value raw materials }\end{array}$ \\
\hline 17 & $\begin{array}{l}\text { Dawuro mpo/yeamene/na } \varepsilon \text { ny n'abaa } \rightarrow \\
\text { Even the gong-gong/has been swallowed/ } \\
\text { how much more its stick } \rightarrow \text { great obstacle/ } \\
\text { one has overcome/relatively minor ones } \\
\text { easily managed } \rightarrow \text { If Ghana advances tech- } \\
\text { nologically enough to manufacture airplanes } \\
\text { and computers/manufacture of simpler } \\
\text { products trivial }\end{array}$ & $\begin{array}{l}\text { If Ghana should advance in tech- } \\
\text { nology enough to begin manufac- } \\
\text { turing industrial equipment and } \\
\text { other challenging products, such } \\
\text { as computers and airplanes as } \\
\text { well as training people to manage } \\
\text { our resources efficiently, it will } \\
\text { get to a time when nothing will } \\
\text { seem impossible for Ghanaians } \\
\text { to do }\end{array}$ \\
\hline
\end{tabular}


Osseo-Asare, K. /Ogya ne atuduro nna faako - Fire and gunpowder do not sleep together

Table 4: Deconstruction of students' discussion of materials connection (part (e) of assignment)

- Group B

\begin{tabular}{|c|c|c|}
\hline $\begin{array}{l}\text { Proverb } \\
\text { No. }\end{array}$ & \begin{tabular}{|l|}
$\begin{array}{l}\text { Deconstruction (Keyword } \\
\text { tracking) }\end{array}$
\end{tabular} & Materials Connection \\
\hline 2 & $\begin{array}{l}\text { Aboa/beka wo/na efiri wo ntoma mu } \\
\rightarrow \text { insect/will bite you/will be from } \\
\text { your cloth } \rightarrow \text { If someone/can harm } \\
\text { you/it is person already near you } \rightarrow \\
\text { natural resources/needed to advance } \\
\text { a given society/must first be sought } \\
\text { locally }\end{array}$ & $\begin{array}{l}\text { If any group of people would } \\
\text { want to develop their environ- } \\
\text { ment, they should consider first } \\
\text { exploiting their natural resourc- } \\
\text { es, rather than thinking that } \\
\text { the basic requirements for their } \\
\text { development is found in other } \\
\text { countries from which they have } \\
\text { to import things. }\end{array}$ \\
\hline 8 & 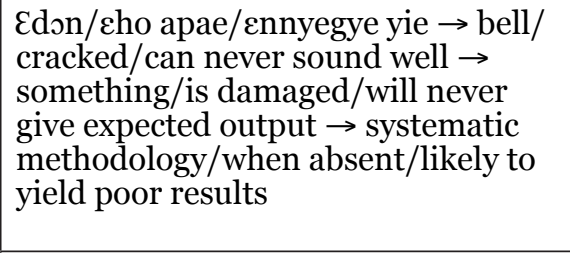 & $\begin{array}{l}\text { In science, great attention is giv- } \\
\text { en to detail, each single process } \\
\text { is crucial to the ultimate target. } \\
\text { Any science project pursued } \\
\text { outside the systematic methodol- } \\
\text { ogy would lead to failure or even } \\
\text { catastrophe in some instances. }\end{array}$ \\
\hline 13 & $\begin{array}{l}\mathrm{T} \varepsilon / \text { tsutswalbi/tse efo/koyn } \mathrm{t} \varepsilon \rightarrow \\
\text { stone/builders passed over/became } \\
\text { huge rock in deep forest } \rightarrow \text { Some- } \\
\text { thing/one views as unimportant/can } \\
\text { become most valuable in the future } \\
\rightarrow \text { girl-child education/once con- } \\
\text { sidered as waste of resources/now } \\
\text { viewed as a necessity }\end{array}$ & $\begin{array}{l}\text { In the immediate past, invest- } \\
\text { ing in girl-child education was } \\
\text { viewed as a waste of resources } \\
\text { since girls were expected to } \\
\text { become housewives primarily. } \\
\text { However, today's economic real- } \\
\text { ities favor dual income families } \\
\text { and girl-child education has } \\
\text { become a necessity. }\end{array}$ \\
\hline 14 & $\begin{array}{l}\text { Tss kome/kpee kosyoso/le ekus } \rightarrow \\
\text { single tree/facing storm/gets broken } \\
\rightarrow \text { a task not shared/confronted by } \\
\text { challenges/tends to fail (Unity is } \\
\text { strength or a given task is most suc- } \\
\text { cessful when it is shared with others) } \\
\rightarrow \text { Ghana alone/confronting malaria } \\
\text { eradication/cannot achieve goal }\end{array}$ & $\begin{array}{l}\text { Considering the recent malaria } \\
\text { prevention program introduced } \\
\text { in Ghana, it may be difficult to } \\
\text { complete the program by Ghana- } \\
\text { ians alone. It therefore calls for } \\
\text { Ghana to collaborate with other } \\
\text { countries or donors to pool re- } \\
\text { sources to enable the program to } \\
\text { be carried out successfully. }\end{array}$ \\
\hline
\end{tabular}

